\title{
UPAYA PENANGANAN LIMBAH OLAHAN IKAN MENJADI PAKAN TERNAK DAN APLIKASINYA TERHADAP BUDIDAYA TERNAK ITIK
}

\author{
Jajat Sudrajat $^{1 *}$, Komariyati ${ }^{1}$, Supriyanto ${ }^{2}$ \\ ${ }^{1}$ Program Studi Agribisnis Universitas Tanjungpura, Pontianak, Indonesia \\ ${ }^{2}$ Program Studi D3 Perkebunan Universitas Tanjungpura, Pontianak, Indonesia \\ *Penulis Korespondensi: sudrajat_jajat83@yahoo.co.id
}

\begin{abstract}
Abstrak
Upaya ini merupakan integrasi antara usaha penanganan limbah pengolahan ikan menjadi pakan ternak dan upaya peningkatan gizi serta pendapatan keluarga kelompok usaha pengolah ikan di Desa Sungai Kakap. Metode yang digunakan dalam pelaksanaan kegiatan adalah sosialisasi, pelatihan, pendampingan, serta monitoring dan evaluasi. Hasil kegiatan menunjukkan tim pelaksana berhasil membangkitkan semangat berwirausaha bagi ibu-ibu anggota kelompok usaha olahan ikan yang tergabung dalam Kelompok Lina Sederhana dan kelompok rumah tangga lainnya. Keberhasilan ditunjukkan berupa peningkatan omzet penjualan melalui pengelolaan sistim produksi dan pemasaran sekaligus menjadi model usaha ramah lingkungan. Kegiatan ini dapat menjadi model pembinaan bagi lembaga terkait dalam meningkatkan keuntungan usaha olahan ikan dan mewujudkan model rumah tangga pangan lestari.
\end{abstract}

Kata kunci: limbah olahan ikan, pakan ternak, ternak itik

\begin{abstract}
This effort is an integration between the handling of fish processing waste as animal feed and the effort to increase the household's nutrition and income of fish processing business group in Sungai Kakap village. The methods is used in the implementation are socialization, training, mentoring, and monitoring and evaluation. The results showed that the team is successful in generating entrepreneurial spirit for the women of fish processing business group belonging to the Lina Sederhana group and other household groups. The success is shown by increasing sales turnover through the management of production and marketing systems as well as being an environmental friendly business model. This activity can be an empowerment model for government institutions in increasing the profit of fish processing business and realizing the model of sustainable food household.
\end{abstract}

Keywords: fish processed waste, animal feed, ducks

\section{PENDAHULUAN}

Kecamatan Sungai Kakap khususnya Desa Sungai Kakap merupakan satu di antara daerah pesisir sebagai penghasil ikan yang potensial di Kalimantan Barat. Berdasarkan hasil wawancara dengan kepala bagian statistik dan produksi perikanan kantor Kelautan dan Perikanan Kabupaten Kubu Raya diperoleh informasi bahwa kondisi perikanan laut di Kecamatan Sungai Kakap masih menunjukkan kondisi yang baik. Produksi perikanan laut di Kecamatan Sungai Kakap mencapai 3.993,60 ton dan sekitar 1.400,20 ton atau $35,06 \%$ berasal dari penghasilan nelayan Desa Sungai Kakap. Desa Sungai Kakap merupakan desa penghasil ikan kedua terbesar setelah Desa Sepok Laut. Terdapat $20,13 \%$ penduduk Desa Sungai Kakap yang berprofesi sebagai nelayan termasuk kelompok pengolah ikan (BPS Kubu Raya, 2016).

Hasil wawancara dengan Kepala Resort Perikanan Kecamatan Sungai Kakap menyatakan bahwa hasil produksi perikanan tangkap di Desa Sungai Kakap sangat beragam yaitu meliputi ikan bilis, kepetek, gulama, layur, kembung, selar, udang rajungan hingga ikan jenis - jenis komersial seperti bawal, kakap, senangin, tenggiri, dan tongkol. Hal senada diiinformasikan oleh Badan Pengelolaan Sumber Daya Pesisir dan Laut (BPSPL) bahwa usaha penangkapan ikan merupakan penyumbang terbesar dari jumlah produksi perikanan di Kabupaten pemekaran ini, yaitu mencapai sekitar $80 \%$ (Anonim, 2016a).

Desa Sungai Kakap memiliki jarak dari pusat pemerintahan Kabupaten Kubu Raya $\pm 38,2 \mathrm{~km}$ dan jarak dari Kota Pontianak $\pm 22 \mathrm{~km}$, yang dapat ditempuh dengan transportasi darat (BPS Kubu Raya, 2016). Di daerah pinggiran Sungai Kakap terdapat kelompok pengolah ikan tradisional yang mengolah sejenis ikan yang sering dikenal dengan ikan Rucah dengan hasil akhir ikan kering tawar maupun asin. Penduduk yang bermata pencaharian ini ada yang bagian dari keluarga nelayan ada yang memang satu 
keluarga menjadi pengolah ikan. Pada umunya mereka merupakan keluarga yang berusia produktif antara 22 hingga 45 tahun dengan anak rerata 3. Kelompok pengolah ikan yang ada di desa Sungai Kakap di antaranya adalah Lina Sederhana yang mempekerjakan buruh harian lepas rata-rata 7-10 orang/hari untuk setiap produksi sebanyak $250 \mathrm{~kg}$ dan pada musim tangkapan yang baik produksi dapat mencapai 1 ton. Anggota Kelompok Lina Sederhana sebanyak 10 orang. Selain Kelompok Lina Sederhana, terdapat juga sekelompok ibu-ibu rumah tangga yang mengolah ikan hasil tangkapan menjadi produk ikan asin, tetapi hanya bekerja pada waktu-waktu tertentu, ketika hasil tangkapan sangat melimpah, sehingga ini hanya dapat dikatakan sebagai usaha sambilan.

Limbah yang dihasilkan dari pengolahan ikan dan atau ikan yang tidak terolah bisa mencapai $10-20 \%$ dari bahan mentah. Oleh karena itu, dalam sehari rata-rata limbah dapat mencapai $25-50 \mathrm{~kg}$ per hari. Limbah ikan setiap harinya semakin bertambah dan belum dimanfaatkan karena kondisi pengetahuan dan ketrampilan masyarakat yang masih terbatas. Limbah ikan dapat berupa ikan yang sudah tidak layak dikonsumsi atau diolah, ataupun dari limbah pengolahan seperti isi perut ikan dan bagian lain yang tidak dikomersialkan. Di desa Sungai Kakap selama ini limbah ikan hanya dibuang ke sungai sehingga pada akhirnya dapat menimbukan permasalahan lingkungan. Oleh karena itu perlu dicari solusi untuk penanganannya, satu di antaranya dengan memanfaatkan menjadi pakan ternak yang mempunyai nilai tambah ekonomi. Pakan ternak ini selanjutnya dapat digunakan untuk mendukung budidaya itik yang juga sangat cocok dibudidayakan di daerah pesisir. Selain untuk konsumsi sendiri, pakan ternak dari limbah olahan ikan yang sudah dikemas dan disertai pemberian label yang tepat akan memiliki nilai jual tinggi yang pada akhirnya dapat meningkatkan pendapatan keluarga.

Pada saat ini satu kesulitan masyarakat di tepi pantai adalah kesulitan dalam memenuhi kebutuhan protein dan sayuran. Para nelayan yang baru pulang melaut sering kali langsung menjual ikannya ke tengkulak/pedagang pengumpul ataupun para pengolah ikan, sehingga justru keluarga nelayan kurang mengkonsumsi ikan hasil tangkapan itu sendiri. Pola konsumsi yang salah menjadi masalah utama masyarakat di tepi pantai karena minimnya pendapatan. Padahal pemeliharaan itik di sekitar pekarangan rumah yang telah dilakukan sebagian besar para pengolah ikan dapat menjadi solusi tepat dalam pemenuhan gizi keluarga dengan ketersediaan telur dan daging itik. Ternak itik yang ada hanya dipelihara sekedarnya, sehingga produksi telur dan daging tidak sesuai harapan.

Di satu sisi, pada saat proses pengeringan pada pengolahan ikan, ada banyak waktu luang/kosong, terutama untuk para pemilik usaha karena hanya menunggu ikan menjadi kering. Hal tersebut menjadi alasan lebih tepat bagi para pengolah ikan untuk memanfaatkan waktu luang tersebut untuk mengolah limbah ikan sehingga dapat menjadi sumber usaha pendapatan alternatif maupun untuk peningkatan gizi keluarga.

Perbaikan produksi olahan ikan dengan pengelolaan administrasi dan keuangan yang sehat diperlukan oleh usaha kecil dan menengah, termasuk Kelompok Usaha Pengolah Ikan untuk peningkatan sumber pendapatan dengan melakukan diversifikasi hasil. Pada akhirnya produksi olahan ikan sesuai standar mutu dan penanganan limbahnya menjadi satu kesatuan usaha dalam mengatasi pencemaran lingkungan sekaligus peningkatan gizi dan pendapatan keluarga.

\section{BAHAN DAN METODE}

Mitra kegiatan ini adalah Kelompok Usaha Pengolahan Ikan "Lina Sederhana" dan Ibu-ibu rumah tangga Dusun Nirwana Desa Sungai Kakap. Kelompok Usaha Pengolahan Ikan Lina Sederhana aktif dalam kegiatan pengolahan ikan segar menjadi ikan asin dan dendeng ikan. Demikian pula, ibu-ibu rumah tangga Dusun Nirwana merupakan ibu-ibu yang mengolah ikan segar menjadi ikan asin, tetapi hanya pada saat-saat tertentu, ketika hasil tangkapan ikan melimpah. Diantara Ibuibu rumah tangga tersebut juga memelihara itik di pekarangan rumahnya.

Metode yang digunakan dalam pelaksanaan kegiatan pengabdian masyarakat adalah sosialisasi, pelatihan, pendampingan, monitoring dan evaluasi. Kegiatan tahap pertama adalah sosialisasi tentang bagaimana sistem jaminan mutu pengelolaan usaha produk olahan ikan, pentingnya penanganan limbah pada usaha produk olahan ikan dan alternatif pemanfaatannya sebagai produk pakan ternak dan perencanaan bisnis produk alternatif dari limbah olahan ikan tersebut.

Tahapan selanjutnya merupakan kegiatan tahap kedua yaitu pelatihan dan pendampingan. Kegiatan ini meliputi penerapan teknologi penanganan limbah pengolahan ikan menjadi pakan ternak dan aplikasinya untuk budidaya ternak itik dan perencanaan bisnis pakan ternak sebagai produk alternatif dari limbah olahan ikan.

Kegiatan tahap ketiga adalah evaluasi dan monitoring. Monitoring dan evaluasi dilakukan dengan indikatorindikator keberhasilan sebagai berikut: 1) Kelompok usaha pengolah ikan dapat menghasilkan produk pakan ternak sebanyak $30 \mathrm{~kg}$ dan dikemas dengan ukuran @ 1 kg, 2) Kelompok usaha pengolah ikan dan ibu-ibu rumah tangga mampu memanfaatkan pakan ternak untuk mendukung budidaya ternak itik sehingga dapat meningkatkan penyediaan sumber pangan keluarga berupa protein, dan 3) Kelompok usaha pengolah ikan dan ibu-ibu rumah tangga dapat menjadi wirausaha yang mampu melakukan administrasi/pembukuan usaha secara sederhana. 


\section{HASIL DAN PEMBAHASAN}

\subsection{Orientasi dan Sosialisasi}

Setelah sosialisasi pertama dan kedua, tentang bagaimana sistem jaminan mutu pengelolaan usaha produk olahan ikan dan pentingnya penanganan limbah pada usaha produk olahan ikan dan alternatif pemanfaatannya sebagai produk pakan ternak telah menambah pengetahuan para anggota kelompok pengolah ikan dan ibu-ibu rumah tangga sehingga memiliki persepsi positif tentang usaha olahan ikan ramah lingkungan. Rata-rata anggota kelompok usaha pengolah ikan dan ibu-ibu rumah tangga yang mengikuti sosialisasi (sekitar $80 \%$ dari total anggota kelompok) telah mengetahui dan memahami materi sosialisasi. Hal tersebut dibuktikan sebanyak $80 \%$ dari peserta mampu menjawab dengan baik pertanyaanpertanyaan yang dituangkan dalam kuesioner tentang materi sosialisasi. Dengan adanya pengetahuan dan persepsi yang positif, diharapkan akan timbul sikap dan tindakan yang positif sehingga setelah pelatihan, para anggota kelompok pengolah ikan dan ibu-ibu rumah tangga mampu melakukan pengelolaan usaha olahan ikan secara optimal dan berkelanjutan.

Sosialisasi ketiga tentang perencanaan bisnis produk pakan ternak. Materi perencanaan bisnis adalah penting karena gagalnya calon wirausaha sering kali akibat tidak mampu merancang perencanaan bisnis (business plan) yang baik. Akibatnya wirausaha baru tersebut ketika memasuki dunia bisnis, banyak hal yang tak terduga muncul dan tak tahu apa yang harus dilakukan (Kasali, 2010). Sosialisasi ini telah membuka wawasan para anggota kelompok pengolah ikan dan ibu-ibu rumah tangga pentingnya merencanakan sebuah usaha, walaupun dengan cara yang sederhana. Sebanyak 20 orang dari 25 orang $(80 \%)$ yang hadir dalam sosialisasi, mampu menjawab dengan baik kuesioner yang telah disiapkan untuk menguji tingkat pengetahuan mereka dalam memahami materi perencanaan bisnis produk pakan ternak sebagai alternatif hasil dari olahan limbah ikan.

\subsection{Pelatihan dan Pendampingan}

Pelatihan penerapan teknologi penanganan limbah pengolahan ikan menjadi pakan ternak dan aplikasinya untuk budidaya ternak itik diawali dengan mempersiapkan alat-alat dan bahan serta brosur sebagai panduan teknis praktis bagi para pengolah ikan dan ibu-ibu rumah tangga agar cepat mengerti dan terampil dalam menerapkan teknologi tersebut. Pada proses pelatihan, ada kerjasama yang sangat baik dalam pelaksanaan yang ditandai dengan sebagian peserta menghancurkan limbah olahan ikan ke dalam mesin pengiling dan sebagian peserta menimbang bahan-bahan, seperti limbah olahan ikan, dedak, jagung dan tepung tapioka dengan komposisi tertentu dan kemudian dicampur menjadi satu untuk dibuat adonan. Setelah menjadi adonan, bahan-bahan tersebut dimasukkan dalam mesin penggiling lagi sehingga terbentuk pakan ternak yang siap dikeringkan di bawah sinar matahari.
Mesin penggiling sebagai alat yang diserahkan ke para pengolah ikan merupakan rakitan dari tim pelaksana pengabdian yang terdiri dari: bagian mesin (bermerek forza), bagian penggiling, dan bagian kaki. Mesin ini memiliki kemampuan mengolah seluruh limbah ikan yang dihasilkan dalam sehari, yaitu $\pm 40 \mathrm{~kg} / \mathrm{hari}$.

Proses pelatihan penerapan teknologi penanganan limbah pengolahan ikan menjadi pakan ternak dan aplikasinya untuk budidaya ternak itik terlaksana dengan lancar. Peserta pelatihan secara sungguhsungguh mengikuti seluruh acara kegiatan. Adanya kesesuaian ternak itik di daerah pantai dan melimpahnya limbah olahan ikan telah mendorong mereka untuk dapat membuat sendiri pakan ternak dan sekaligus mengaplikasikan pakan ternak tersebut untuk mendukung keberhasilan budidaya itik.

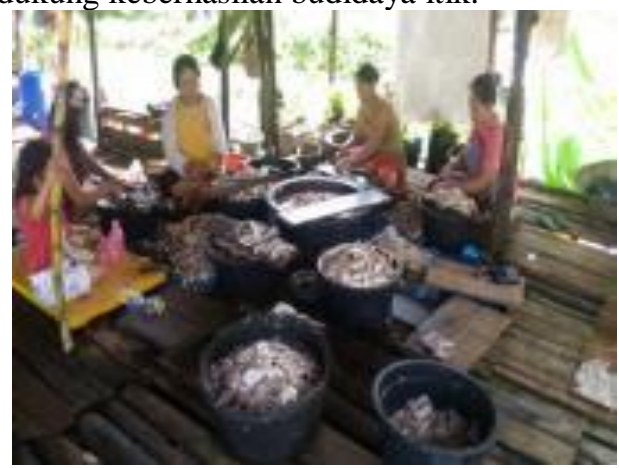

Gambar 1.

Kegiatan Pengolahan Ikan

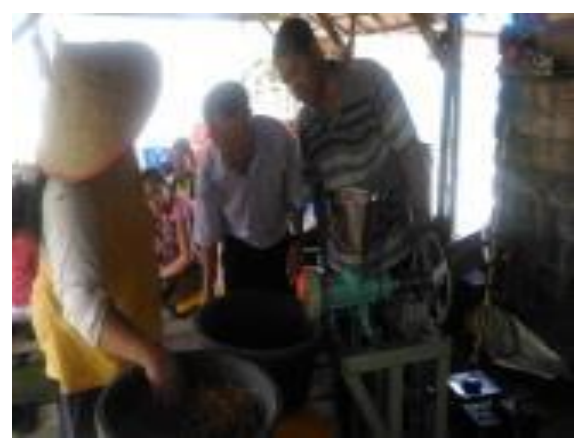

Gambar 2.

Proses Pelatihan Pembuatan Pakan Ternak

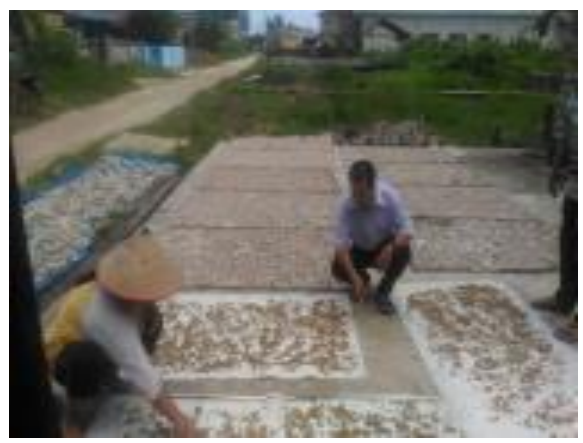

Gambar 3.

Proses Pengeringan Pakan Ternak

Kendala yang ditemukan pada waktu pelatihan adalah peserta pelatihan relatif lambat dalam memahami dan 
menerapkan teknologi pemanfaatan limbah olahan ikan. Diduga faktor pendidikan peserta pelatihan yang relatif rendah (rata- rata lulusan SD) menjadi faktor penyebab mereka mengalami kesulitan dalam aplikasinya.

Pada hari ke 14 (empat belas) setelah pelatihan, dilakukan kunjungan sebagai bentuk pendampingan kegiatan pembuatan pakan ternak. Pembuatan pakan ternak menggunakan mesin yang telah dirakit dan dipusatkan di rumah ketua kelompok usaha pengolah ikan yang sekaligus sebagai tempat usaha. Pada saat kunjungan dalam rangka pendampingan tersebut, anggota kelompok usaha pengolah ikan mampu mengolah limbah ikan sebanyak $40 \mathrm{~kg}$. Hal ini dirasa masih kurang mengingat produksi limbah dari usaha olahan ikan segar mencapai $20 \%$, padahal setiap harinya kelompok olahan ikan saja mampu memproduksi atau mengolah ikan segar rata-rata $200 \mathrm{~kg} / \mathrm{hari}$. Kesadaran dan kesabaran perlu ditingkatkan agar pengelolaan limbah olahan ikan dapat dilaksanakan secara berkelanjutan.

Pelatihan dan pendampingan perencanaan bisnis produk pakan ternak dilakukan terhadap kedua mitra. Materi pelatihan perencanaan bisnis ini dimulai dengan menuliskan kembali data usaha, seperti nama usaha, bidang usaha, jenis produk/jasa, alamat usaha, nomor telepon, mulai berdiri, dan sebagainya. Kemudian peserta diajak untuk menghitung kebutuhan bahan habis pakai, peralatan dan sebagainya. Pembukuan yang sederhana menjadikan pebisnis akan lebih teliti dan mengetahui keuntungan dan kerugian usaha yang dijalani (Anonim, 2016b). Perencanaan usaha atau bisnis, terutama pembuatan administrasi pembukuan masih perlu pendampingan secara intensif. Hal ini terlihat pada saat pendampingan, daya serap peserta pelatihan hanya mencapai $50 \%$.

\subsection{Monitoring dan Evaluasi}

Pelaksanaan monitoring dan evaluasi dilakukan setelah selesai tahapan pelatihan dan pendampingan dalam penerapan teknologi. Evaluasi dilakukan secara berkala. Berdasarkan hasil monitoring dan evaluasi inilah, tim pelaksana mengetahui kekurangan dan kesalahan dari proses pelatihan yang bisa berdampak pada kurang berhasilnya para pengolah ikan dan ibu-ibu rumah tangga dalam penerapan teknologi yang diintroduksikan.

Penghargaan sederhana telah dilakukan oleh tim pelaksana pengabdian terhadap pengolah ikan dan ibu rumah tangga yang telah berhasil dalam menerapkan teknologi yang diintroduksikan. Kata-kata pujian yang bisa membangkitkan motivasi serta adanya sedikit tambahan bantuan bahan pembuatan pakan ternak mampu meningkatkan semangat dan kemauan untuk menerapkan teknologi yang lebih baik. Demikian juga, bagi pengolah ikan dan ibu rumah tangga yang belum berhasil melakukan teknologi yang diintroduksikan melalui sosialisasi dan pelatihan dipacu lagi semangat atau kemauannya untuk lebih tahu, mau dan mampu dalam menerapkan teknologi tersebut.

Monitoring dan evaluasi secara internal yang dilakukan oleh tim pelaksana kegiatan pengabdian terhadap pembuatan pakan ternak dan perencanaan bisnis. Saat ini para pengolah ikan yang tergabung dalam Kelompok Lina Sederhana telah berhasil memproduksi pakan ternak sebanyak $120 \mathrm{~kg}$ setiap minggunya. Produksi pakan tersebut merupakan hasil produksi dari gabungan limbah olahan ikan sebanyak $40 \mathrm{~kg}$, dedak $40 \mathrm{~kg}$, jagung $30 \mathrm{~kg}$ dan tepung kanji sekitar $10 \mathrm{~kg}$. Jika setiap harinya kelompok ini memproduksi limbah ikan 20\% dari ikan segar, maka sebenarnya para pengolah ikan belum sepenuhnya memanfaatkan limbah ikan untuk pakan ternak. Hal ini disebabkan terbatasnya tenaga kerja mereka yang lebih dicurahkan untuk memproduksi ikan kering.

Hasil monitoring dan evaluasi juga menunjukkan bahwa peserta pelatihan telah mampu menghitung biaya-biaya yang harus dikeluarkan dalam proses penanganan limbah olahan ikan menjadi pakan ternak sekaligus mengaplikasikan untuk budidaya ternak itik. Banyaknya peternak yang gagal dalam usaha beternak itik petelur, diakibatkan penghasilan yang tidak sebanding dengan modal yang harus dikeluarkan. Hal ini umumnya disebabkan tingginya kebutuhan pakan dengan protein dan kalori yang cukup setiap harinya (Anonim. 2009). Tersedianya limbah ikan sesungguhnya sudah cukup membantu bubidaya itik di desa ini. Sebagian ibu rumah tangga membeli dari para pengolah ikan dan sebagian lainnya merupakan limbah dari olahan ikan milik sendiri, sehingga hal ini bisa mengurangi biaya produksi dalam budidaya itik petelur. Penyediaan pakan seperti ini selaras dengan pendapat Budi, dkk. (2015), bahwa pakan racikan hasil olahan sendiri cenderung lebih murah apabila dibandingkan dengan pakan jadi berupa pellet yang berasal dari pabrik pakan ternak.

Materi pelatihan perencanaan bisnis produk pakan ternak dimulai dengan menuliskan kembali data usaha, seperti nama usaha, bidang usaha, jenis produk/jasa, alamat usaha, nomor telepon, mulai berdiri, dan sebagainya. Kemudian peserta diajak untuk menghitung kebutuhan bahan habis pakai dan peralatan yang diperlukan. Pengenalan adanya pembukuan diharapkan menjadikan pengusaha kecil ini akan lebih teliti dalam mengetahui keuntungan dan kerugian usaha yang dijalani (Anonim, 2016b). Untuk kasus ini, praktek penyusunan rencana dan ketertiban pembukuan masih memerlukan pendampingan secara intensif karena daya serap peserta pelatihan pada materi ini hanya $50 \%$.

Kemampuan dalam memproduksi pakan ternak dari limbah ikan sebagai bahan utama dan kemampuan dalam membuat perencanaan bisnis, diharapkan manajemen internal dan eksternal kelompok rumah tangga sasaran dapat meningkat. Pada akhirnya 
tercapai keberlanjutan produksi serta ke depan diharapkan memiliki peluang yang lebih baik dalam pemasarannya.

\section{SIMPULAN DAN SARAN \\ 4.1 Simpulan}

Simpulan dari kegiatan pengabdian masyarakat dengan khalayak sasaran kelompok usaha pengolah ikan dan ibu-ibu rumah tangga di Desa Sungai Kakap, Kubu Raya-Kalimantan Barat adalah: 1) Penerapan teknologi pembuatan pakan ternak dapat menjadi solusi dalam permasalahan penanganan limbah olahan ikan 2) Penerapan teknologi pembuatan pakan ternak dapat langsung diaplikasikan untuk mendukung budidaya itik yang banyak dilakukan oleh ibu-ibu rumah tangga di Desa Sungai Kakap, sehingga dapat meningkatkan gizi dan pendapatan rumah tangga.

\subsection{Saran}

Mengingat nilai manfaat teknologi yang diintroduksikan bagi pengolah ikan ataupun ibu-ibu rumah tangga sangat tinggi, maka pada tahap selanjutnya sangat diperlukan pendampingan secara intensif di dua mitra yang menjadi kelompok sasaran, yaitu Kelompok Usaha Pengolah Ikan "Lina Sederhana" dan ibu-ibu rumah tangga. Selain itu, penerapannya juga dapat diperluas ke masyarakat di sekitarnya di Desa Sungai Kakap, sehingg menjadi kegiatan andalan dalam meningkatkan pendapatan rumah tangga.

\section{UCAPAN TERIMA KASIH}

Terimakasih kepada Direktorat Riset dan Pengabdian Masyarakat Ditjen Penguatan Riset dan Pengembangan Kementerian Riset, Teknologi dan Pendidikan Tinggi dan Rektor Universitas Tanjungpura melalui Ketua LPPKM UNTAN, yang telah memfasilitasi dan mendanai pengabdian pada masyarakat ini. Penulis juga mengucapkan terimaksih yang sebesar-besarnya kepada Kepala Desa Sungai Kakap, ketua dan anggota Kelompok Usaha Lina Sederhana serta ibu-ibu rumah tangga dan semua pihak yang mendukung dalam kegiatan ini.

\section{DAFTAR PUSTAKA}

Anonim. 2009. Pakan Alami, Perkecil Biaya Produksi Peternakan Itik. http://sutanmuda.wordpress.com. (Diakses Tanggal 20 Mei 2017)

Anonim. 2016a. Badan Pengelolaan Sumber Daya Pesisir dan Laut (BPSPL) Provinsi Kalimantan Barat

Anonim. 2016b. Pembukuan Keuangan Sederhana Memulai Usaha Kecil. https://www.akun.biz/tips-bisnis/pembukuankeuangan-usaha/. (Diakses tanggal 19 Februari 2017)

Badan Pusat Statistik Kubu Raya, 2016. Kecamatan Sungai Kakap dalam Angka Tahun 2015. BPS. Kubu Raya

Budi E.S., Yektiningsih E., dan Priyanto E. 2015. Profitabilitas Usaha Ternak Itik Petelur di
Desa Kebonsari Kecamatan Candi, Sidoarjo. Jurnal Agraris, 1(1), 32-37, DOI: 10.18196/agr.115

Kasali R. 2010. Wirausaha Muda Mandiri (Independent Young Entrepreneur). Gramedia Pustaka Utama. Jakarta 